\title{
Greek Identity in the Middle Ages
}

L'identité grecque au Moyen Âge

Speros Vryonis

\section{(2) OpenEdition \\ Journals}

Electronic version

URL: http://journals.openedition.org/etudesbalkaniques/394

ISSN: $2102-5525$

\section{Publisher}

Association Pierre Belon

\section{Printed version}

Date of publication: 1 January 1999

Number of pages: 19-36

ISBN: 2-910860-09-4

ISSN: $1260-2116$

\section{Electronic reference}

Speros Vryonis, « Greek Identity in the Middle Ages », Études balkaniques [Online], 6| 1999, Online since 08 April 2009, connection on 25 April 2019. URL : http://journals.openedition.org/ etudesbalkaniques/394

This text was automatically generated on 25 April 2019.

Tous droits réservés 


\title{
Greek Identity in the Middle Ages
}

L'identité grecque au Moyen Âge

\author{
Speros Vryonis
}

AUTHOR

SPEROS VRYONIS

The Speros Basil Vryonis Center for the Study of Hellenism, California 